\title{
Pareto analysis of critical factors affecting technical institution evaluation
}

\author{
Victor Gambhir $^{a^{*}}$, N.C. Wadhwa ${ }^{b}$ and Sandeep Grover ${ }^{b}$
}

${ }^{a}$ Manav Rachna International University, India

${ }^{b}$ YMCA University of Science \& Technology, Faridabad, India

\begin{tabular}{|c|c|}
\hline$\overline{\text { ART I C LE I N FO }}$ & A B S T R A C T \\
\hline $\begin{array}{l}\text { Article history: } \\
\text { Received December 20, } 2011 \\
\text { Received in Revised form } \\
\text { March, 25, } 2012 \\
\text { Accepted 23 April } 2012 \\
\text { Available online } \\
\text { April 27 2012 } \\
\text { Keywords: } \\
\text { Critical factors } \\
\text { Technical institution evaluation } \\
\text { Pareto analysis }\end{array}$ & $\begin{array}{l}\text { With the change of education policy in 1991, more and more technical institutions are being set } \\
\text { up in India. Some of these institutions provide quality education, but others are merely } \\
\text { concentrating on quantity. These stakeholders are in a state of confusion about decision to } \\
\text { select the best institute for their higher educational studies. Although various agencies including } \\
\text { print media provide ranking of these institutions every year, but their results are controversial } \\
\text { and biased. In this paper, the authors have made an endeavor to find the critical factors for } \\
\text { technical institution evaluation from literature survey. A Pareto analysis has also been } \\
\text { performed to find the intensity of these critical factors in evaluation. This will not only help the } \\
\text { stake holders in taking right decisions but will also help the management of institutions in } \\
\text { benchmarking for identifying the most important critical areas to improve the existing system. } \\
\text { This will in turn help Indian economy. }\end{array}$ \\
\hline
\end{tabular}

\section{Introduction}

Over the recent years, technical education in India has gone through rapid, radical and even revolutionary changes. This has generated opportunities to open technical institutions with business orientation. Thousands of technical institutions have come into existence since 1992 in India. Some of these institutions are very good and have realized the importance of quality but there are many insitituations with low level of required educational requirenments. So students are in a great confusion to select the best institution for their higher studies. Every year entrance exams are conducted in India and students have a lot of options in terms of institution according to their ranking. Although many agencies provide ranking of the institutions every year but these ranking are contradictory and instead of solving the problem, alleviate it. Moreover these rankings seem to be influenced or biased. An engineer with the thorough knowledge places a great role in Indian economy than to an engineer holding just a graduate degree. Even the technical institutions themselves want to be benchmark with the peers for improvement. So the problem of technical

* Corresponding author. Tel: +989126980426

E-mail addresses: gambhirvictor@hotmail.com (V. Gambhir)

(C) 2012 Growing Science Ltd. All rights reserved.

doi: 10.5267/j.msl.2012.04.018 
institution evaluation is important for everyone and has great role to play in everyone's life because everybody is associated with education in one or other way. Seeing the importance of the problem, the authors have made an endeavor to find the critical factors for technical institution evaluation from literature survey. Many researchers in the past have identified different factors for institution evaluation but as per authors' knowledge no literature review has been attempted in the past to collect all critical factors at a single place. A Pareto analysis has also been attempted to know the critical factor intensity in evaluating technical institution.

In this paper a total of 35 quality research papers have been reviewed to find the critical factors. To find the good papers all the leading search engines as well as renowned publishing houses such as Elsevier, Taylor \& Francis, Inderscience, Springer \& Emerald have been searched. The remaining paper is organized as follows. Section 2 deals with identification of critical factors. Section 3 discusses pareto analysis and conclusion is provided at the end.

\section{Identification of critical factors}

Table 1 lists the critical factors with the name of the contributors. 40 factors were identified but with the opinions of experts and academicians these were reduced to 23, because other factors were either similar or they seem to be less important.

\section{Table 1}

List of Critical Factors for Technical Institution Evaluation

\begin{tabular}{|c|c|}
\hline Critical Factors & Contributors \\
\hline 1. A well accepted vision and mission & $\begin{array}{l}\text { Lisensky (1988), Sherr and Tecter (1991), Nadeau (1993), The Conference } \\
\text { Board (1993), Downey et al. (1994), Finch (1994), Lewis and Smith (1994), } \\
\text { Burkhalter (1996), Frazier (1997), Madhavan (1997) }\end{array}$ \\
\hline 2. Clearly defined and specific goals & Seldin (1988), Lawton (1994), Billing (1996) \\
\hline 3. Effective and efficient leadership & $\begin{array}{l}\text { Reid et al. (1987), Teauber (1987), Scheerens (1989,1992), Lezotte (1989), } \\
\text { Rossow (1990), West-Burnham (1992), Nadeau (1993), Oakland (1993), The } \\
\text { Conference Board (1993), Finch (1994), Dahlagaard et al. (1995), Spanbaurer } \\
\text { (1995), Lozier and Tecter (1996), William (1996), Frazier (1997), Scheerens } \\
\text { and Bosker (1997), Tang Zairi (1998) }\end{array}$ \\
\hline 4. Clear \& specific policies \& procedures & Tang and Ziari (1998) \\
\hline 5. Strategic \& operational planning & $\begin{array}{l}\text { Shirley (1988), Lisensky (1988), Binney (1992), Finch (1994), Frazier (1997), } \\
\text { Owlia and Aspinwall (1997), Tamg and Zairi (1994) }\end{array}$ \\
\hline 6. Clear organizational structure and design & West Burnham(1992), Downey et al.,(1994), Lewis and Smith(1994) \\
\hline 7. Delegation of authority/ power distribution & Developed by self \\
\hline 8. Budget priorities-proactive \& objective driven & Finch (1994) \\
\hline 9. Well defined curriculum design & Adapted by Frazier (1997) \\
\hline 10. Suitability \& relevance of curriculum content & Adapted by Frazier (1997) \\
\hline 11. Curriculum planning, design, periodic review & Frazier (1997) \\
\hline $\begin{array}{l}\text { 12. Instructional competence-Expertise and } \\
\text { adequacy }\end{array}$ & Trethowan (1987), also adapted from Pratt and Steanning (1989) \\
\hline $\begin{array}{l}\text { 13. Instructional arrangement - class size, adequate } \\
\text { infrastructure \& facilities }\end{array}$ & Developed by self \\
\hline 14. Adaptive recourse allocation & Developed by self \\
\hline $\begin{array}{l}\text { 15. Adequate and competent administrative staff/ } \\
\text { support staff. }\end{array}$ & Adapted from Owlia and Aspinwall(1998) \\
\hline 16. Trustworthiness amongst all & Owlia and Aspinwall(1998) \\
\hline 17. Well defined channels of communication & $\begin{array}{l}\text { Murgatroyd and Morgan (1993), the conference board(1993), Oakland and } \\
\text { Oakland (1998), Gurnani (1999) }\end{array}$ \\
\hline 18. Customer focus/ need based & $\begin{array}{l}\text { Binney (1992), Marchington (1992), West Burnham(1992), Downey et } \\
\text { al.,(1994), Dahlgaard et al.(1995), Spanbauer(1995), Lozier and Teeter(1996), } \\
\text { Owlia and Aspinwall(1998), Sirvanci(1996), Boaden(1997), Frazier(1997), } \\
\text { Madhavan (1997), Gurmami(1999) }\end{array}$ \\
\hline 19. Reward policy and Incentives Schemes & Binney(1992), the conference board (1993), Raisbeck(1994), Gurnani (1999) \\
\hline 20.clear and well defined values and norms & Rutter et al.,(1979) \\
\hline $\begin{array}{l}\text { 21. Differentiation- adaptive service for its } \\
\text { customers }\end{array}$ & Horne and Pierce(1996), Scheerners and Boasker (1997) \\
\hline 22.Emphasis on training and development for all & $\begin{array}{l}\text { The conference board (1993), Raisbeck (1994), Spanbauer (1995),Lozier and } \\
\text { Teeter(1996), Boaden (1997), Owlia and Aspinwall(1997), Oakland and } \\
\text { Oakland (1998), Gurnani(1989) }\end{array}$ \\
\hline 23.Collaborative decision making & Lewis and Smith(1994), Pashiardis (1998) \\
\hline
\end{tabular}


These 23 factors are further divided into four clusters by consulting with experts, which are shown in Fig.1.

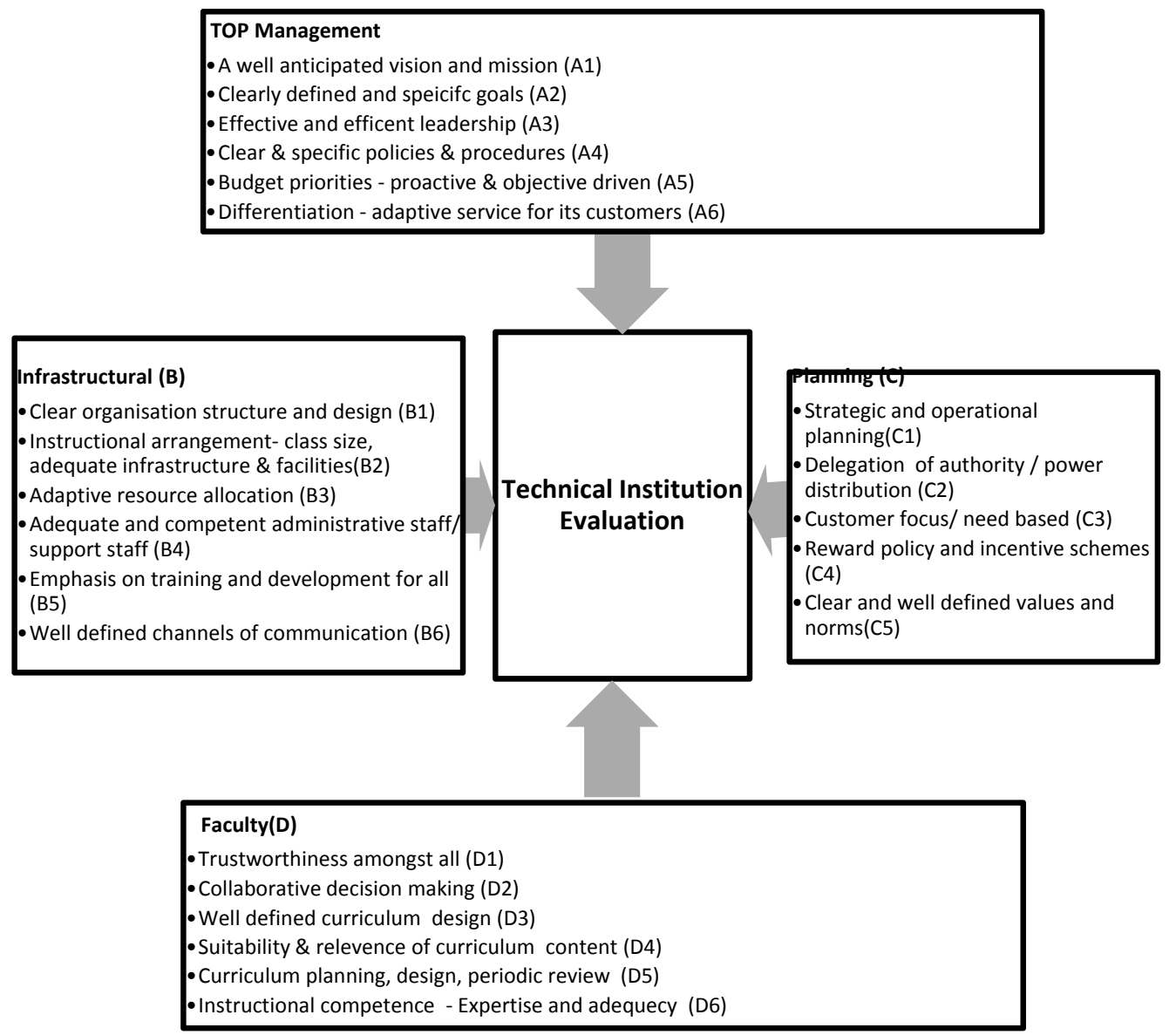

Fig.1. Technical Institution Evaluation clusters and detailed criteria

\section{Pareto analysis of critical factors for technical institution evaluation}

Pareto diagrams are named after Vilfredo Pareto , who studied the distribution of wealth in $19^{\text {th }}$ century Italy, that is, the number of people in various income classes. Juran (1989) extended this idea beyond the principle of wealth to problems in general. Pareto diagram are a special type of histogram, which helps determine which factors are most important and in what order they contribute. The bars in Pareto diagrams are rearranged in descending order of their heights, showing the individual contribution of each factor as well as the cumulative contributions. The purpose is to identify high priority items by separating the "vital few" from the "trivial many". The preparation of Pareto diagram follows the following steps:

- Identify the factors to be compared and arrange them in desired order,

- Select standards for comparison or categories into which you want to group the data,

- Collect data and total the occurrences in each data category,

- List categories from left to right on the horizontal axis in descending order - from largest to smallest, 
- Draw bars representing the frequency of the items,

- Calculate the cumulative frequencies and percentages,

- Construct a cumulative line graph.

The factors reported by the selected articles were extracted and presented in a Table 1 . The factors that were recommended by the authors for effective evaluation were included in the Pareto analysis. The Pareto analysis of factors compiled from selected articles is presented in Tables 2 and Fig.2. Top Management has come at the top with 64\% literature support while other factors occurs at only $36 \%$.

Table 2

Pareto Analysis Data

\begin{tabular}{llll}
\hline Critical Factors & No. of Articles & Cumulative \% & Cut off \% \\
\hline Top Management & 34 & $64 \%$ & 0.8 \\
Infrastructural & 5 & $74 \%$ & 0.8 \\
Planning & 4 & $81 \%$ & 0.8 \\
Faculty & 10 & $100 \%$ & 0.8 \\
\hline
\end{tabular}

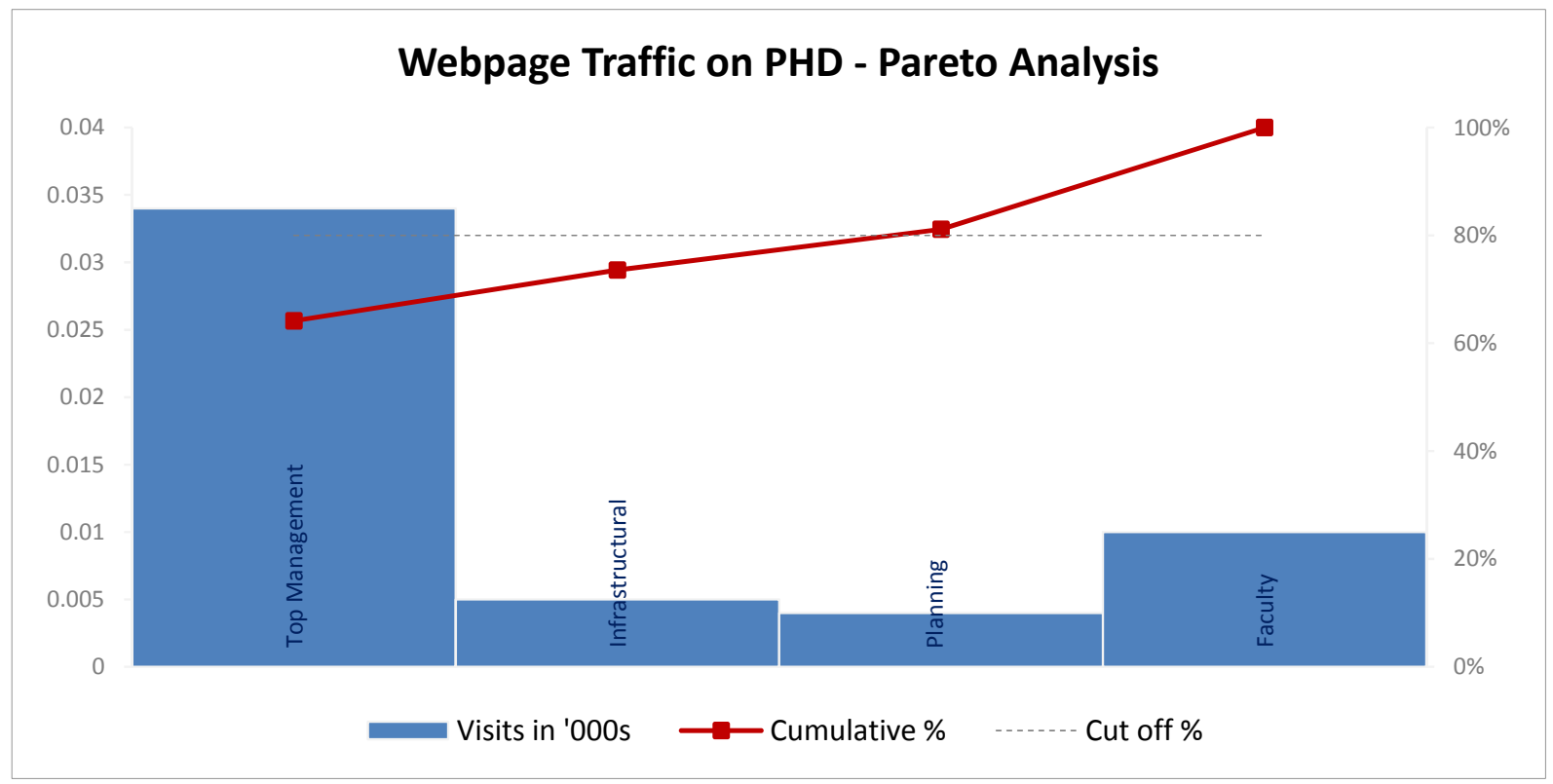

Fig. 2. Pareto Analysis

\section{Conclusion}

Technical institution evaluation is important for stakeholders, management as well as for strong economy of India. Critical factors have been identified from literature survey and pareto analysis has been carried out to now the intensity of these factors in evaluation. The pareto analysis shows that top management is the most target factor in literature. This seems to be right because if the vision and policies of the top management are correct and in the best interest of stakeholders and institution then definitely everyone will be beneficial. The second important factors come out to be faculty which is the pillar of any good technical institution The third important factors comes out to be planning, which is another most critical factor because all depends upon building right planning in the starting and in the last infrastructural factor comes. A good infrastructure will definitely produce more opportunities to provide the class education. 


\section{Acknowledgment}

The authors would like to thank the annonymous referees for their constructive comments on earlier version of this paper.

\section{References}

Bitner, M. (1990). Servicescapes: The impact of physical surroundings on customers and employees. Journal of Marketing, 57-71.

Brady, M. C. (2001). Some new thoughts on conceptualizing perceived service quality: a hierarchical approach. Journal of Marketing, 65, 34-49.

Chaston, I. (1994). Are British universities in a position to consider implementing TQM? Higher Education Quality, 48(2), 118-134.

Cheng, Y. (1996). The Pursuit of School Effectiveness: Theory, Policy and Research. The Hong Kong Institute of Educational Research, The Chinese University of Hong Kong, Hong Kong.

Cronin, J. T. (2002). Measuring service quality: a re-examination and extension. Journal of Marketing, 56, 56-58.

Elmuti, D. K. (1996). Are total quality management programmers in higher education worth the effort? International Journal of Quality \& Reliability Management, 13(6), 29-44.

Eriksen, S. (1995). TQM and the transformation from an elite to a mass system of higher education in the UK. Quality Assurance in Education, 3(1), 14-29.

Green, d. (1994). What is quality in higher education? Concepts, policies and practice. in Green, D. (Eds), What is Quality in Higher Education? SRHE and Open University Press, Buckingham, 320.

Haywood-Farmer, J. (1988). A conceptual model of service quality", International Journal of Operations \& Production Management. 8(6), 19-29.

Killedar, M. (2007). Model for Total Quality' of the Open and Distance Education System. Total Quality Management, 8, 402-415.

Levinson, H. B.-J. (1996). Managing quality improvement on a development pilot line. Quality Management Journal, 3(2), 16-35.

Madu, C. K. (1994). 56, 375-390.

Madu, C. K. (1994). TQM in the university: a quality code of honor. Total Quality Management, 56, 375-390.

Michael, R. S. (1997). A comprehensive model for implementing TQM in higher education. Benchmarking for Quality Management and Technology, 4(2), 17.

Mukhopadhay, M. (2001). Total Quality Management in Education, National Institute of Educational Planning and Administration. New Delhi.

Mukhopadhyay, M. (2005). Total quality management in higher education. International Journal of Educational Management, 5(5), 4-9.

Owlia, M. A. (1998). A framework for measuring quality in engineering education. Total Quality Management, 9(6), 501-518.

Parasuraman, A. Z. (1985). SERVQUAL: a multiple-item scale for measuring consumer perceptions of service quality. Journal of Retailing, 64(1), 12-40.

Pfeffer, N. C. (1991, november 24). Is Quality Good For You? A Critical review of Quality Assurance in the Welfare Services. Institute of Public Policy Research TQM in Education, 64-65.

Reeves, C. B. (1994). Defining quality: alternatives and implications. Academy of Management Review, 19(3), 419-445.

Sahney, S. B. (2004). Customer requirement constructs: the premise for TQM in education: a comparative study of select engineering and management institutions in the Indian context. International Journal of Productivity and Performance Management, 53(6), 499-520.

Sallis, E. (1993). Total Quality Management in Education. Kogan Page, 45-47. 
Spanbauer, S. (1995). Reactivating higher education with total quality management: using quality and productivity concepts, techniques and tools to improve higher education. Total Quality Management, 6(5), 519-537.

Tobin, L. (1990). The new quality landscape: total quality management. Journal of System Management, 41, 10-14.

Walsh, A. H. (2002). Total quality management continuous improvement: is the philosophy a reality? Journal of European Industrial Training, 26(6), 299-307.

Willis, P. (1999). Total quality management: some thoughts. Higher Education, 25(3), 373-375.

Zeithaml, V. P., Berry, L.L., \& Parasuraman, A. (1985). Problems and strategies in services marketing. Journal of Marketing, 49, 33-46. 